\title{
O problema da eficácia da sentença ${ }^{*}$
}

\section{Carlos Alberto Álvaro de Oliveira ${ }^{* *}$}

1. Problema delicado que tem sobremaneira ocupado a atenção dos processualistas, principalmente nos últimos tempos, diz respeito à questão da eficácia da sentença no processo de conhecimento, às vezes situado exclusivamente no campo do direito processual, outras vezes no domínio do direito material, sem que até agora se tivesse logrado, pelo menos na minha ótica, uma solução satisfatória. Esse interesse tem sido redobrado, principalmente, em vista da tomada de consciência de que para o processualista dos dias atuais não basta apenas elaborar conceitos (tarefa útil, não há dúvida), mas de que é preciso elaborálos levando em conta a efetividade do instrumento jurisdicional.

No presente ensaio, busca-se, em primeiro lugar, determinar o estado atual do problema (itens 2 e 3 ); num segundo momento, examinar com espírito crítico as teorias correntes sobre o assunto (itens 4 e 5) e, finalmente, reelaborar uma concepção mais afim às exigências do dia (item 6).

2. Na doutrina brasileira, exsurgem claramente duas posições a respeito do tema.

O entendimento tradicional vincula a eficácia da sentença à espécie de tutela jurisdicional concedida à parte, adotando a usual classificação ternária das sentenças em declaratórias (positivas ou negativas), constitutivas (positivas ou negativas) e condenatórias.

Para Humberto Theodoro Junior, por exemplo, "A classificação realmente importante das sentenças (considerando tanto a decisão do juiz singular como o acórdão dos tribunais)

\footnotetext{
"Ensaio destinado a integrar livro em homenagem a Giuseppe Tarzia.

"* Professor titular da Faculdade de Direito da UFRGS; doutor em Direito.
} 
é a que leva em conta a natureza do bem jurídico visado pelo julgamento, ou seja, a espécie de tutela jurisdicional concedida à parte." Dentro dessa perspectiva, classifica ele as sentenças em condenatórias, constitutivas e declaratórias. Já as sentenças mandamentais e executivas, - como comandos a serem cumpridos dentro do mesmo processo em que a sentença foi proferida - não são essencialmente diversas das três categorias clássicas: "Tanto as que se dizem executivas como as mandamentais realizam a essência das condenatórias, isto é, declaram a situação jurídica dos litigantes e ordenam uma prestação de uma parte em favor da outra. A forma de realizar processualmente essa prestação, isto é, de executá-la, é que diverge. A diferença reside, pois, na execução e respectivo procedimento. Sendo assim, não há razão para atribuir uma natureza diferente a tais sentenças."'

Cândido Rangel Dinamarco, embora com certos temperamentos, também compartilha desse modo de pensar.

Ressalta que a classificação das ações, cara à doutrina clássica do processo civil, segundo a espécie de sentença que se pede no exercício de cada uma delas, tem o mérito de ser puramente processual, evitando os critérios herdados da tradição romana e impregnados de elementos inerentes ao direito subjetivo afirmado pelo autor (real, pessoal, etc.). Diz, também, mostrar-se mais coerente com a moderna visão do processo civil classificar as demandas, como concretas iniciativas de pedir a tutela jurisdicional. ${ }^{2}$ A classificação é ternária: sentenças declaratórias, constitutivas e condenatórias. As mandamentais integrariam a classe das condenatórias: "A sentença mandamental é título para a execução forçada, tanto quanto a condenação ordinária - e portanto é também uma condenação. A diferença está no conteúdo da sanção imposta em seu segundo momento, na qual se exacerba o fator comando, ou mandamento [...] O comando contido em tais sentenças é de tal intensidade, que autoriza o juiz, ainda no processo de conhecimento e sem necessidade de propositura ou instalação do executivo, a desencadear medidas destinadas a proporcionar ao vencedor a efetiva satisfação de seu direito."3 Adiante reforça esse entendimento: “[...] não se trata de uma quarta categoria sentencial, ao lado da

1 THEODORO JÚNIOR, Humberto. Curso de Direito Processual Civil. 39. ed. Rio de Janeiro: Forense, 2003, v. 1, n' 497 , p. 468-469, n 499 , p. 470.

2 DINAMARCO, Cândido Rangel. Instituições de Direito Processual Civil. 2. ed. São Paulo, Malheiros, 2002, v. 3, n 894, p. 204-205.

3 DINAMARCO, Instituições..., nº 919, p. 242-243. 
meramente declaratória, da condenatória e da constitutiva. Por sua estrutura, função e eficácia, as sentenças mandamentais compartilham da natureza condenatória, sem embargo do reforço de eficácia que lhes outorga a lei." ${ }^{\prime 4}$

Nada obstante, admite Cândido Rangel Dinamarco a subclasse das sentenças executivas lato sensu, quando a sentença condenatória comportar execução no mesmo processo em que foi proferida, sem necessidade de ser instaurado formalmente o processo executivo. Para o jurista, esses casos são raros e excepcionais no sistema e só existem na medida em que o direito positivo os permita especificamente, como nas ações de despejo, nas possessórias, nas desapropriações imobiliárias e poucas outras. ${ }^{5}$

3. A outra corrente origina-se das idéias elaboradas por Pontes de Miranda, depois retomadas e desenvolvidas por Ovídio A. Baptista da Silva.

Sustenta Pontes de Miranda, em primeiro lugar, que a eficácia da sentença está umbilicalmente vinculada à ação exercida. Significativamente ao falar de ação, sem aspas (portanto, no significado de ação de direito material que lhe empresta), afirma que "A ação, que supõe haver-se transgredido a norma, constitui outro plus e tende, não à prestação, mas a efeito jurídico específico." Adiante repisa: "Enquanto o direito subjetivo e a pretensão tendem à prestação, a ação supõe combatividade e, pois, tende, não à prestação, mas a efeito jurídico específico." Nessa perspectiva, "O conceito de ação, a classificação das ações por sua eficácia, tudo isso consulta o direito material, porque o fim precípuo do processo é a realização do direito objetivo. Na própria classificação das ações e das sentenças, o direito processual tem de atender à eficácia das ações segundo o direito material. A margem de liberdade que se lhe deixa é pequena, mas existe." ${ }^{\prime}$

Para Pontes de Miranda, "As ações ou são declarativas (note-se que as relações jurídicas de que são conteúdo direitos e pretensões, ou de que direitos ou pretensões derivam, antes de tudo existem); ou são constitutivas (positivas ou negativas; isto é, geradoras ou modificativas, ou extintivas); ou são condenatórias; ou são mandamentais; ou são executivas", ${ }^{9}$ pois, as

4 Ibidem, n919, p. 245.

5 Ibidem, n 920, p. 245-246.

6 PONTES DEMIRANDA. Tratado das Ações. São Paulo: Revista dos Tribunais, 1970, v. 1, p. 33.

7 Ibidem, p. 93.

8 Ibidem, p. 126.

9 Ibidem, p. 117. 
classificações de ações de que usaram os juristas europeus estão superadas. Assim,

a classificação binária como a classificação ternária (ação declaratória, ação constitutiva, ação condenatória) não resistem às críticas e concorreram para confusões enormes que ainda hoje estalam nos espiritos de alguns juristas, como também não viam que uma coisa é força de sentença (eficácia preponderante) e outra a eficácia imediata ou mediata, sem sefalar nas duas menores, com que se completa a constante da eficácia das ações e das sentenças. ${ }^{10}$

Consoante Pontes de Miranda, a classificação correta é a quinária, com as seguintes notas distintivas: a) "A ação declarativa é ação a respeito de ser ou não-ser a relação jurídica"; b) "De regra, a ação constitutiva prendese à pretensão constitutiva, res deducta, quando se exerce a pretensão à tutela jurídica. Quando a ação constitutiva é ligada ao direito, imediatamente, não há, no plano da res in iudicium deducta, pretensão constitutiva (há-a, no plano do direito subjetivo à tutela jurídica, que é a especialização, pelo exercício da pretensão à tutela jurídica em pretensão constitutiva)"; c) "A ação de condenação supõe que aquele ou aqueles, a quem ela se dirige tenham obrado contra direito, que tenham causado dano e mereçam, por isso, ser condenados (con-damnare)"; d) "A ação mandamental prende-se a atos que o juiz ou outra autoridade deve mandar que se pratique. $O$ juiz expede o mandado, porque o autor tem pretensão ao mandamento e, exercendo a pretensão à tutela jurídica, propôs a ação mandamental"; e) "A ação executiva é aquela pela qual se passa para a esfera jurídica de alguém o que nela devia estar, e não está."

$\mathrm{Na}$ mesma esteira posiciona-se Ovídio A. Baptista da Silva: "Reafirmando, pois, o que já ficou dito, podemos distinguir bem as duas formas de agir e, portanto, as duas espécies

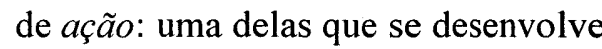
no plano do direito material e corresponde ao agir contra o obrigado para a realização do direito, independentemente de sua colaboração; a outra, dirigida contra o Estado, para que ele provocado pelo interessado (autor), exerça a atividade jurisdicional a que se obrigou e preste a respectiva tutela, dando resposta adequada ao pedido. A primeira espécie de ação tem como pressuposto um direito material preexistente de que é titular aquele que age; esta, a "ação" processual, por força há de estar igualmente fundada num direito anterior. Também ela, como qualquer outra atividade lícita, deve corresponder a um direito exigível (= pretensão), sob pena

10 Ibidem, p. 118.

11 PONTES DE MIRANDA, Tratado das..., p. 118-122. 
de configurar o puro arbítrio e a violência." Mais adiante afirma que "Aquele que age (exerce ação) no plano do processo absolutamente não pode prescindir da atividade do Estado para a realização do direito do autor à jurisdição. Ao contrário, o exercício da "ação", aqui, é tanto o agir quanto o exigir que o Estado aja, prestando tutela jurídica."12

Em tema de classificação das ações, pondera ainda o jurista:

Quando pretendemos classificar o ato jurisdicional típico - decisões e sentenças, tanto do "processo de conhecimento" quanto do processo de execução por créditos -, teremos de examinar e ordenar o produto desta atividade estatal conforme os efeitos que cada um deles produz no mundo jurídico, de acordo com o respectivo verbo por meio do qual o ato sentencial reflete a ação de direito material correspondente, contida na demanda, de que a decisão judicial de procedência é conseqüência necessária.

Levando em conta esse critério, divide as sentenças em declaratórias, constitutivas, condenatórias, executivas e mandamentais, "conforme a pretensão material do autor vitorioso seja dirigida a obter a simples declaração de existência ou inexistência de uma determinada relação jurídica; ou tenha por fim sua constituição, modificação ou extinção; ou colime a simples condenação do demandado a cumprir uma obrigação; ou finalmente tenha por objeto obter, desde logo, a realização do direito litigioso no processo de conhecimento, mediante um ato de execução praticado pelo juízo, ou através de um simples mandado ou ordem que o magistrado emita, como porção do conteúdo do ato sentencial."13 Mais adiante, acentua: "Quando se diz que as ações - e as respectivas sentenças de procedencia - podem ser declaratórias, constitutivas ou condenatórias, está-se a indicar ações de direito material afirmadas existentes, na correspondente petição inicial, e que na perspectiva da relação jurídica processual concreta onde elas se apresentam não serão mais do que simples hipóteses de trabalho com que o magistrado se depara" (grifos do original) ${ }^{14}$

4. Claro está que mostra-se insuficiente a vinculação a fatores unicamente processuais. Com razão, pondera Ovídio A. Baptista da Silva, que a "ação" processual una e abstrata não pode ter conteúdo declaratório, constitutivo ou condenatório, sem tornar-se "azioni della tradizione

12 SILVA, Ovídio A. Baptista da. Curso de Processo Civil. 5. ed. rev. e atual. São Paulo: Revista dos Tribunais, 2000, v. 1, p. 92-93.

13 Ibidem, v. 1, p. 112.

14 SILVA, Curso..., v. 1, p. 160. 
civilistica" e prossegue afirmando que "O prodígio de alguma coisa que, não tendo substância, por ser igual a si mesma, e a todos indistintamente concedida, possa ser declaratória, constitutiva ou condenatória, é uma contradição que não chega a ofender a racionalidade dos juristas que lidam com processo." 15

Por outro ângulo visual, a idéia da ação abstrata parece não levar na devida conta que as diversas formas procedimentais reagem também sobre a ação, o agir em juízo, determinando poderes, faculdades e ônus diversos: um só ato é comum a todo o tipo de ação (decorrente do poder abstrato de colocar em andamento o procedimento), mas os outros atos posteriores podem ter dimensão diversa, em razão do objeto do processo, da forma, etc. ${ }^{16} \mathrm{E}$ isso porque não parece possível afastar a ligação com o direito material, em virtude da ínsita instrumentalidade que a função jurisdicional exerce em relação a este, a que servem a ação e o processo, por meio do exercício dos poderes, faculdades e ônus titulados pelas partes.

Todo o processo está impregnado do direito material. Como bem ressalta Fazzalari, o autor alega fatos, mas não qualquer "episódio da vida" e sim fatos que, enquadrando-se no esquema de uma norma, geram determinadas conseqüências jurídicas, deduzindo assim os fatos constitutivos da situação jurídica (substancial) preexistente, e antes de tudo, a situação fática concreta da qual deriva a posição de proeminência em relação ao bem, vale dizer o direito subjetivo (substancial). Trata-se é claro de direito afirmado, que logo passa a ser objeto da controvérsia e termina por se apresentar (na hipótese da sentença de acolhimento) como realidade declarada. ${ }^{17}$ Outro ponto de confluência é o pedido imediato, que contém a especificação da tutela jurisdicional pretendida (declarar, condenar, constituir, mandar, executar), estreitamente vinculada ao direito material. A própria lesão afirmada pelo autor, que conduz à insatisfação de uma situação material protegida e evidencia o interesse na tutela jurisdicional reclamada, diz respeito ao direito material.

Tudo isso demonstra não ser possível emprestar à eficácia da sentença um caráter puramente processual.

5. Por outro lado, tampouco satisfaz a invocação ao conceito equívoco de ação de direito material.

A esse respeito Pontes de Miranda tece as seguintes considerações:

15 SILVA, Ovídio A. Baptista da. Jurisdição e Execução na tradição romano-canônica. São Paulo: Revista dos Tribunais, 1996, p. 179.

16 Assim, FAZZALARI, Elio. Note in tema di diritto e processo. Milano: Giuffrè, 1953, p. 151 , nota 129 .

17 Ibidem, p. 122-123. 
O exercer pretensão, ou ação, ou exceção, que se contém no direito, é exercer o direito. A alguns poderes correspondem ações para se realizarem ou serem 'declarados'. Aqui está um dos pontos mais relevantes da Teoria Geral do Direito: em todo direito, pretensão, ação ou exceção, tem-se como incluido o elemento poder de revelar-se, se alguém obsta ou dificulta ou nega a revelabilidade. Esse poder de revelar-se é actio e corresponde ao conteúdo favorável da sentença quando se exerce a pretensão à tutela jurídica. ${ }^{18}$

A ação (de direito material) é inflamação do direito ou da pretensão. ${ }^{19}$ Por sua vez, "A 'ação' "é outro grau em que já se confere a alguém, autor, titular da ação (nota: ação de direito material), o reclamar, através ou por meio de ato, a verificação, a atuação da lei". ${ }^{20}$ A "ação" exerce-se junto com a ação. ${ }^{21}$

Quando se afirma que "a ação (de direito material) é inflamação do direito ou da pretensão", logo surgem à lembrança as idéias de Savigny, que via a ação de direito material como emanação (Ausfluss) do próprio direito material, confundindo-se com a eficácia deste. Para tanto distinguia ele entre os direitos em si (Rechten an sich), os direitos lesionados (verletzten Rechten) e os direitos em estado de defesa (im Zustand der Vertheidigung), ${ }^{22}$ todos aspectos do direito material. Ao inserir a ação no plano do direito material, tal modo de visualizar o problema deixa obviamente de levar em conta a necessária separação entre os planos do direito material e processual.

Ora, se não é possível afirmar a existência do direito antes do contraditório, muito menos se poderá admitir a "ação material" já no início da demanda. Sua existência só poderá ser averiguada no final do processo, com o trânsito em julgado da sentença, quando então se confundirá com a eficácia da própria sentença.

Para salvar essa evidente contradição, Pontes de Miranda sustenta que o direito à pretensão à tutela jurídica (rectius: pretensão à outorga de justiça) de modo nenhum é pretensão à sentença favorável: $:^{23}$

Se, em vez de se alcançar, com trânsito em julgado, sentença favorável, por ser julgada improcedente a ação (= propôs-

18 PONTES DE MIRANDA, Tratado das..., p., 67.

19 PONTES DE MIRANDA, Tratado das..., p. 116.

20 Ibidem, p. 277.

21 Ibidem, p. 94-95, 110.

22 SAVIGNY. System des heutigen römischen Rechts. Berlin, 1841, v. 5, p. 1-2, §§ 204-205.

23 PONTES DE MIRANDA. Comentários ao Código de Processo Civil. Rio de Janeiro, Forense, 1974, v. 1, p. XXXIV. 
se ação que o demandante não tinha), declara-se a inexistência da ação. Uma vez que o autor não tinha a ação, exerceu pretensão à tutela jurídica, exerceu a pretensão ao remédio iurídico processual, porque não podia esperar sentença favorável quanto à ação de que se supunha ser titular. ${ }^{24}$

A explicação não satisfaz, porque ao mesmo tempo em que se reconhece que o demandante não tinha ação (de direito material) afirma-se que a ação foi exercida pela "ação". Não se pode exercer o que não se tem, é o óbvio.

Ovídio A. Baptista da Silva, por sua vez, concebe a ação de direito material, inerente a todo o direito, como "um agir do titular do direito para sua realização, independentemente da vontade ou do comportamento do obrigado" (grifos do original). ${ }^{25} \mathrm{Em}$ outra passagem, conceitua-a "como o agir próprio de cada direito, capaz independentemente de qualquer participação ativa do obrigado - de realizar inteiramente o respectivo direito". ${ }^{26}$ Acentua, também, que

a realização coativa do direito, com absoluta prescindência da vontade ou da colaboração do obrigado, que se consegue através da jurisdição, é rigorosamente a mesma ação de direito material, ou seja, o mesmo agir para a realização inerente a todo o direito, com a única diferença que, proibida a autotutela privada, a efetivação do direito se dá através da ação dos órgãos estatais. Portanto, longe de haver supressão ou substituição, da ação de direito material, o que em verdade ocorreu foi uma duplicação de ações: uma dirigida contra o obrigado, outra endereçada contra o Estado, para que este, uma vez certificada a existência do direito, o realize coativamente praticando a mesma atividade de que fora impedido seu titular" (grifos do original).27

Apesar da assertiva, casos há em que se torna indispensável a participação ativa do obrigado, o que retira validade ao conceito, ou pelo menos à generalidade que se lhe pretende atribuir. Assim ocorre, por exemplo, como admite Ovídio A. Baptista da Silva, no ato de dar posse ao servidor público, o que inviabilizaria a realização direta, por parte do juiz, do direito reconhecido na sentença. ${ }^{28}$ Ainda, para ser coerente com as idéias que defende, o jurista passou a negar também a existência da ação condenatória, pois o agir realizador da pretensão será a ação de execução, no caso execução obrigacional. ${ }^{29}$ Ressalta

24 Ibidem, p. XLIII-XLIV.

25 SILVA, Curso...., v. 1, p. 80.

26 Ibidem, v. 2, p. 354-355.

27 SILVA, Curso..., v. 2, p. 84-85.

28 Ibidem, v. 2, p. 354-355.

29 Ibidem, v.2, p. 204. 
aí a fragilidade da teoria, pois é inegável que, mesmo na ausência da ação de direito material nessas hipóteses, a sentença (condenatória ou mandamental) continuaria mantendo toda eficácia que lhe é própria.

Por outro lado, não se constata a pretendida duplicação de ações em certas demandas constitutivas, positivas ou negativas, despidas de pretensão material, a exemplo da demanda de divórcio, de anulação de casamento e de interdição. Da mesma forma, impensável a duplicação de ações no que concerne à pretensão declaratória, pois o titular do direito não pode agir por si mesmo para sua realização com ou sem vontade do obrigado: a declaração do próprio interessado de seu próprio direito seria um flatus vocis, tornando-se indispensável a certificação que exsurge da autoridade estatal, com o exercício da jurisdição e o acolhimento da demanda.

Aliás, aliar o conceito de ação de direito material à titularidade do direito ("um agir do titular do direito") já denuncia um certo comprometimento com as teorias imanentistas da ação (Savigny), embora sempre negado.
Uma vez posto em discussão o direito, não se pode ainda falar em sujeito que dele seja titular, mas apenas de pretendente a esse reconhecimento, que poderá ou não ocorrer, dependendo da sorte da sentença.

Além disso, a imanência do direito material, que estaria presente em todas as ações de direito material (observo tratar-se da própria eficácia do direito material), induz a pensar numa concepção intimamente vinculada ao direito justicial material civil de James Goldschmidt (também ele concretista, não se esqueça). Esse direito, integrado pelas normas que regulam a tutela jurisdicional e pelas próprias normas de direito privado, seria totalmente distinto deste último, e entendido não como regulador da conduta dos particulares, mas do juízo e da atividade do juiz. Para o grande jurista alemão, as normas de direito privado se endereçariam ao particular e, ao mesmo tempo, ao juiz, que deveria lhes garantir a atuação, ou, o que resulta no mesmo, regulariam tanto a conduta do particular quanto a sanção que é imposta pelo Estado. ${ }^{30}$ Nessa visão, o direito privado material e o direito justicial material seriam

30 GOLDSCHMIDT, James. Zivilprozessrecht. 2. ed. Berlin, 1932, Aalen, Scientia Verlag, $1969, \S 2,3$, p. 5 (na trad. espanhola de Leonardo Prieto Castro, Barcelona, Labor, 1936, p. 8): "Pode-se compreender o direito como um conjunto de imperativos aos sujeitos de direito e também como medidas de aplicação para o juiz. Esta última concepção é adequada ao direito justicial e também ao direito processual civil. Desse ponto de vista, as regras jurídicas servem como normas inibitórias ou permissivas, de uma determinada conduta por parte dos particulares, e ainda como padrão para uma sentença jurisdicional com determinado conteúdo." 
apenas dois lados de um único e mesmo domínio jurídico. ${ }^{31}$ Mais importante ainda, assim como Savigny trata a acionabilidade como uma questão de direito material, Goldschmidt também atribui à acionabilidade justicial civil um significado material, vinculando-a ao direito material. ${ }^{32}$ Sintomaticamente, a inserção do fenômeno processual no direito material torna o conceito de ação de Goldschmidt semelhante àquele da actio de Savigny. ${ }^{33}$

Como se vê, a concepção de Goldschmidt sujeita-se às censuras, por demais conhecidas, que são efetuadas às idéias de Savigny. Ademais, não padece dúvida de que as normas reguladoras do processo, geralmente de direito público, dirigidas especialmente à função jurisdicional, não se preocupam diretamente com o direito material pretendido, e ao mesmo tempo o sujeito da conduta prevista na norma de direito material certamente não é o órgão judicial. ${ }^{34}$

A mesma crítica pode ser endereçada ao conceito de ação de direito material, que é um agir derivado do direito material (normas dirigidas ao particular), e que mesmo assim seria exercido no processo por meio do órgão judicial, juntamente com a "ação" processual. A idéia de uma norma de conduta que contenha dentro de si o mecanismo de sua própria realização judicial, acaso violada, de modo nenhum

31 GOLDSCHMIDT, James. Über Begriff und Bedeutung des materiellen Ziviljustizrechts (primeiro dos ensaios denominados Zwei Beiträge zum materiellen Ziviljustizrecht). In: FESTGABE für Heinrich Brünner, München, Leipzig: Duncker, Humblot, 1914, p. 109-138, esp. p. 123.

32 GOLDSCHMIDT, Zivilprozessrecht, § 12, 3, p. 52, trad. p. 96: “A ação processual, como objeto concreto do processo (o meritum causae) é um direito justicial de caráter material, não de caráter processual".

33 Observação de KOLLMANN, Andreas. Begriffs- und Problemgeschichte des Verhältnisses von formellem und materiellem Recht. Berlin, Duncker, Humblot, 1996, p. 598.

34 FAZZALARI, Note in tema..., p. 49, criticando o já mencionado pensamento de Goldschmidt, observa com razão que toda atividade, prevista e valorizada em abstrato na norma, tem o seu próprio sujeito, também indicado na norma. Da constância dessa indicação abstrata e típica, chega-se à conclusão de que toda norma concerne a uma certa categoria de sujeitos (aqueles que venham a se encontrar, concretamente, nas condições descritas na norma), a qual pode também coincidir, mas nem sempre e necessariamente coincide com a generalidade dos sujeitos. Nesses termos, se poderá então concluir que existem normas que indicam como sujeito das condutas nelas descritas e valorizadas o juiz; outras, que indicam os particulares; outras ainda, que indicam o legislador, a administração pública e assim por diante. Daí ser impossível sustentar que a norma de direito privado se dirija ao particular e, ao mesmo tempo, ao juiz que deve garantir sua observância; entender, assim, que a norma de qua regule, ao mesmo tempo, a conduta e a sanção. 
se afina com o ordenamento jurídico brasileiro, que distingue claramente $o$ plano do direito material e o plano do direito processual. É como admitir a existência de uma norma de primeiro grau que, ao mesmo tempo, fosse de segundo grau. ${ }^{35}$

Não bastasse isso, não se vê como possa o juiz agir materialmente (exercer ação de direito material, diriam Pontes de Miranda e Ovídio A. Baptista da Silva) de modo paralelo à ação processual: o que ele faz é desempenhar os atos de seu ofício, mediante o exercício dos poderes que lhe são conferidos por regras de direito público, totalmente distintas das regras de direito privado. Só depois de tomada a decisão (seja antecipatória, seja a própria sentença de mérito) é que o juiz pode em tese interferir no mundo sensível, agindo, mas aí já se trata do resultado da tutela jurisdicional, da própria eficácia da sentença. Antes disso, como é óbvio, não teria havido ação de direito material. Mesmo assim, esse agir do juiz não pode ser equiparado, pura e simplesmente, ao agir do particular, dada a natureza diferenciada da tutela jurisdicional e a forma substitutiva de que se reveste, destinada a reconstruir a realidade fora do processo e não apenas a reproduzi-la.
6. Estabelecido não se assentar a eficácia da sentença apenas em considerações de ordem processual e muito menos se confundir com a ação de direito material, mostra-se indispensável ir mais fundo no exame do problema.

Deve-se atentar em que o direito material constitui a matéria prima com que irá trabalhar o juiz, mas sob uma luz necessariamente diversa. $O$ resultado desse trabalho, que é a tutela jurisdicional, refletida na eficácia da sentença, já não apresenta o direito material em estado puro, mas transformado, em outro nível qualitativo. O provimento jurisdicional, embora certamente se apóie no direito material, apresenta outra força, outra eficácia, e com aquele não se confunde, porque, além de constituir resultado de trabalho de reconstrução e até de criação por parte do órgão judicial, exibe o selo da autoridade estatal, proferida a decisão com as garantias do devido processo legal. Tanto é assim que declarar, condenar, constituir, executar ou mandar são verbos que não constam do repertório do direito material. Este fala em indenizar, em resolver contrato, em renúncia de direito, etc. De notar, aliás, que mesmo a autotutela, que seria a ação de direito material em estado puro,

35 Como bem explicita BOBBIO, Norberto. Norme Primarie e Norme Secondarie. In: STUDI per una Teoria Generale del Diritto. Torino: Giappichelli, 1970, p. 196, em complementação ao pensamento de Santi Romano, os numerosos mecanismos ou engrenagens, os coligamentos de autoridade e força, que produzem, modificam, aplicam e garantem as normas jurídicas constituem também eles normas, exatamente as normas de segundo grau. 
não se equivale, como é óbvio, à tutela jurisdicional, porque ainda sujeita a futura e eventual revisão judicial, despida que é do selo da autoridade estatal, realizada de forma parcializada pelo próprio interessado, sem as garantias do devido processo legal.

Nesse contexto, a eficácia se apresenta apenas como uma forma da tutela jurisdicional, outorgada a quem tenha razão, seja o autor, seja o réu (sentença declaratória negativa). ${ }^{36}$

Por outro lado, a distinção entre as diversas espécies de tutela jurisdicional não é arbitrária.

Deve-se atender, essencialmente, aos princípios da efetividade ${ }^{37}$ e da segurança (este derivado do próprio
Estado de Direito e representado pelo conceito de "devido processo legal"), ambos com matriz constitucional, e ainda à situação jurídica substancial afirmada. Esses princípios informadores é que determinam as espécies possíveis de tutela jurisdicional in abstracto.

Concretamente, a tutela vai depender ainda do pedido formulado pelo autor e das exceções de direito material suscitadas pelo demandado, assim como da configuração (constitucional, material e processual) específica de cada ordenamento jurídico, que constituem todavia elementos externos ao conceito abstrato. Em razão do princípio dispositivo, mostra-se possível a existência de espécies

36 Em outra perspectiva, observa acertadamente YARSHELL, Flávio Luiz., Tutela Jurisdicional Específica nas obrigações de Declaração de Vontade. São Paulo: Malheiros, 1993 , p. 19, que mesmo se pensando em tutela exclusivamente como proteção, ainda assim ela terá estado evidentemente presente em face do vencido na exata medida em que o Estado lhe assegurou, através do exercício da função jurisdicional e do devido processo legal, a resolução do conflito segundo regras pré-estabelecidas e garantidoras de sua participação (procedimento em contraditório) no resultado final da decisão, decisão essa prolatada por julgador cuja imparcialidade vem, inclusive, revestida de inafastáveis garantias de modo a impedir a supremacia do mais forte sobre o mais fraco.

37 Embora já seja um lugar comum, mantém toda a atualidade a consideração fundamental de CHIOVENDA, Giuseppe. Della azione nascente dal contratto preliminare. In: SAGGI di diritto processuale civile. Roma: Foro Italiano, 1930, v. 1, p. 110, no sentido de que "il processo deve dare per quanto è possibile praticamente a chi ha un diritto tutto quello $\mathrm{e}$ proprio quello ch'egli ha diritto di conseguire." MARINONI, Luiz Guilherme Tutela Inibitória (individual e coletiva). 3. ed. São Paulo: Revista dos Tribunais, 2003, p. 449, embora defendendo posição diversa, acentua que a tutela jurisdicional deve ser classificada a partir do que efetivamente faz para atender ao direito material, e não apenas em razão da espécie do efeito jurídico declarado, ressaltando que a preocupação deve se centrar com o resultado que o processo deve proporcionar para que a tutela seja efetivamente prestada ao jurisdicionado. A respeito da efetividade e sua moldura constitucional, as magníficas observações de GUERRA, Marcelo Lima. Execução Indireta. São Paulo: Revista dos Tribunais, 1998, p. 48-54. 
diversas de demandas e de sentenças para uma mesma relação de direito material. Como exemplo pode ser apontada a possibilidade de declaração da relação jurídica, mesmo tendo ocorrido a violação do direito, permitida no art. $4^{\circ}$, parágrafo único, do CPC. A violação do direito, em tese, poderia dar lugar também a demanda mandamental, condenatória ou executiva. Nem por isso, pode-se afirmar, em face das considerações já desenvolvidas, que a classificação das sentenças (ternária ou quinária) constitua um fenômeno puramente processual. ${ }^{38}$

Presentes essas coordenadas, deve ser dada preferência à tutela que conceda a maior efetividade possível. Ao ângulo visual da segurança, importa fundamentalmente possa o direito de defesa do demandado ser exercido de maneira adequada. ${ }^{39}$ A situação jurídica substancial afirmada não deve impedir, outrossim, a eficácia pretendida.

Veja-se, por exemplo, a questão das obrigações de dar dinheiro. Em tal hipótese, a tutela condenatória é a mais adequada, visto que a futura execução por meios sub-rogatórios, por ela proporcionada, em regra é a mais efetiva.

O campo propício ao emprego da tutela mandamental é o dos direitos absolutos, porque estes fazem surgir o dever negativo de abstenção, de não invadir a esfera jurídica alheia, de alterum non laedere. ${ }^{40}$

Inexiste, porém, qualquer razão, como bem pondera Luiz Guilherme Marinoni, ${ }^{41}$ para se estabelecer uma relação necessária entre direitos absolutos e sentença mandamental. Também as obrigações de fazer e não fazer podem ser objeto de tutela mandamental. Mesmo no que concerne aos direitos relativos se reconhece hoje o dever de abstenção: todos os direitos são relativos em relação ao objeto e absolutos no que concerne a sua inviolabilidade (oponibilidade) por parte dos sujeitos do ordenamento. A distinçã̃o está na forma como podem ser realizados ou exigidos: os absolutos realizam seu conteúdo independen-

38 Como preconizam, v.g., ROSENBERG; SCHWAB. Zivilprozessrecht. 12. ed. München: Beck, 1977, §93, 3, p. 478.

39 Às vezes, impõe-se ao juiz a ponderação entre esses dois valores, como sucede com a tutela de urgência, mas a observação é realizada apenas de passagem, porque este estudo está centrado nas eficácias decorrentes da sentença no processo de conhecimento. 40 MARINONI, Tutela.., p. 415.

41 Ibidem, p. 418. TALAMINI, Eduardo. Tutela Relativa aos Deveres de Fazer e de Não Fazer. São Paulo: Revista dos Tribunais, 2001, p. 125-127, com base em amplo estudo da doutrina do direito civil, relativiza a distinção entre deveres e obrigações, preconizando acertadamente a aplicação do art. 461 do CPC tanto aos deveres quanto às obrigações de fazer e não fazer. 
temente da colaboração alheia; os relativos, na relação com outros sujeitos, cujo comportamento é instrumental para sua realização. ${ }^{42} \mathrm{~A}$ explicação é válida em parte, porque nas obrigações de fazer não está em causa o dever de abstenção. Aqui, a tutela mandamental encontra justificativa no princípio da efetividade.

De qualquer modo, a questão foi grandemente facilitada no direito brasileiro, em razão do novo tratamento do cumprimento das obrigações de fazer ou não fazer operado pelo art. 461 do CPC e especialmente, quanto ao ponto, por seu $\S 1^{\circ}$ (Lei 8.952, de 13.12.1994). Por essa norma, deu-se a inversão do princípio Nemo praecise poteste cogi ad factum (ninguém pode precisamente ser coagido a fazer alguma coisa): "A obrigação somente se converterá em perdas e danos se o autor o requerer ou se impossível a tutela específica ou a obtenção do resultado prático correspondente."Afastou-se, assim, a leitura equivocada dos glosadores, privilegiando-se, do ponto de vista do direito material, o respeito à força do negócio jurídico ou do contrato, banidos é claro os meios que violentem a pessoa ou a dignidade do devedor, permitindo-se o constrangimento indireto.

Se a obrigação de fazer é personalíssima, só realizável pelo obrigado (e.g., prestação de obra de arte ou científica), ou se foi convencionado no negócio jurídico que o cumprimento não seria específico, mostra-se adequada a tutela condenatória. $\mathrm{Na}$ obrigação de fazer fungível, que por hipótese pode ser prestada por terceiro às custas do obrigado, $\mathrm{o}$ autor pode escolher entre a sentença condenatória e a mandamental. Esse o sentido da multa estabelecida pelo art. 287 do CPC (redação de acordo com a Lei 10.444, de 7.5.2002). ${ }^{43}$

A tutela declaratória só pode se relacionar com a declaração da existência ou inexistência de uma relação jurídica (excepcionalmente: falsidade de documento). A declaração de um mero fato ou do alcance de uma norma jurídica abstratamente considerada, hipóteses em que não se verifica incidência concreta da norma jurídica sobre o suporte fático, comprometeria a garantia de ampla defesa do demandado, seja porque um mesmo fato pode ser relevante para inúmeros e diversos efeitos jurídicos, seja porque a norma geral e abstrata pode ser aplicada numa série indefinida de situações concretas. ${ }^{44}$

A tutela executiva lato sensu diz respeito apenas à agressão ao próprio patrimônio do autor - linha divisória entre tutela executiva lato sensu e a

42 Cf. COMPORTI, Marco. Diritti reali in generale, p. 26-27, apud MARINONI, op. cit., p. 417 .

43 MARINONI, Tutela..., p. 460-462, com base especialmente no princípio da efetividade. 44 PISANI, Andrea Proto. Appunti sulla Giustizia Civile. Bari: Cacucci, 1982, p. 92-94. 
tutela condenatória (Pontes de Miranda) - porque a agressão de patrimônio alheio requer, por hipótese, maiores possibilidades de defesa (princípio da segurança).

A tutela mandamental, embora atue como a executiva lato sensu, por meio de emissão de ordens do juiz, desta se diferencia porque age sobre a vontade da parte e não sobre o seu patrimônio. Assim o exige a situação jurídica substancial porque a natureza da obrigação não recomenda, dentro da idéia da maior efetividade possível, o emprego da tutela condenatória. ${ }^{45}$

Realmente, tanto a tutela executiva lato sensu quanto a mandamental atendem ao princípio da maior efetividade possível. Basta pensar em relação a esta última que o resultado específico não poderia ser obtido mediante a simples condenação, porquanto conduziria apenas à obtenção do equivalente em dinheiro, com o emprego dos meios sub-rogatórios de execução.

De outro lado, não parece adequado confundi-las com a tutela condenatória sob o argumento de que esta também contém ordem de prestação, variando apenas a forma de realização. ${ }^{46} \mathrm{E}$ isso porque a sentença condenatória não contém ordem de cumprimento da prestação, mas somente juízo de reprovação. Trata-se apenas de exortação ao cumprimento da obrigação, tanto é assim que o descumprimento não está sujeito a qualquer sanção penal ou civil.

Pretende-se, ainda, como já foi ressaltado no início deste ensaio, que a sentença mandamental constitui título para a execução forçada, tanto quanto a condenação ordinária - e assim é também uma condenação, só se diferenciando no conteúdo da sanção imposta em seu segundo momento, na qual se exacerba o fator comando, ou mandamento. ${ }^{47}$ Todavia, a diferença está no próprio conteúdo da sentença, porque os dois verbos mandar e condenar são totalmente distintos, com conseqüências jurídicas distintas: o mandamento atua sobre a vontade do demandado, por meios de coerção, a condenação tende a atuar sobre o patrimônio, em outro processo futuro (efeito executivo da condenação), mediante meios sub-rogatórios. Ora, segundo a melhor doutrina, na primeira hipótese não se trata de verdadeira execução, porque a satisfação do credor é obtida com' a colaboração do devedor, constrangido a cumprir sua obrigação para evitar males maiores. ${ }^{48}$

45 De modo diverso, entende MARINONI, op. cit., p. 398, que o critério que permite definir a mandamentalidade é puramente processual.

46 É a posição de THEODORO JúNIOR, Curso..., v. 1, nº 497, p. 468-469, nº 499, p. 470, já mencionada ao início deste trabalho.

47 DINAMARCO, Instituições..., n 919, p. 242-243.

48 Cf., por exemplo, LIEBMAN, Enrico Tullio. Processo de Execução. 3. ed.. São Paulo, Saraiva, $n^{\circ} 3$, p. 6. 
Cumpre ainda sublinhar que as cinco espécies de tutela (declaratória, condenatória, constitutiva, mandamental e executiva lato sensu) constituem todas, fenômenos jurídicos, mas é preciso considerar que as sentenças declaratórias e constitutivas satisfazem por si mesmas a pretensão processual, sem necessidade de qualquer ato material futuro; a condenatória fica a meio caminho, criando apenas as condições jurídicas, com a constituição do título executivo, para que tal possa ocorrer em processo autônomo e

\section{REFERÊNCIAS}

BOBBIO, Norberto. Norme Primarie e Norme Secondarie. In: STUDI per una Teoria Generale del Diritto. Torino: Giappichelli, 1970.

CHIOVENDA, Giuseppe. Della azione nascente dal contratto preliminare. In: SAGGI di diritto processuale civile. Roma: Foro Italiano, 1930. v. 1

DINAMARCO, Cândido Rangel. Instituições de Direito Processual Civil. 2. ed. São Paulo, Malheiros, 2002. v. 3.

FAZZALARI, Elio. Note in tema di diritto e processo. Milano: Giuffrè, 1953.

GOLDSCHMIDT, James. Über Begriff und Bedeutung des materiellen Ziviljustizrechts (primeiro dos ensaios denominados Zwei Beiträge zum materiellen Ziviljustizrecht). In: FESTGABE für independente, dito de execução; as duas últimas satisfazem no mesmo processo, por meio de atos materiais, realizados depois da sentença, aptos a produzir alterações no mundo fático.

Finalmente, em se cuidando de tutela mandamental ou executiva lato sensu, o ofício jurisdicional só se considera cumprido e acabado com a realização do direito reconhecido na sentença. $\mathrm{O}$ art. 463 do CPC implica apenas veto a que depois de publicada a sentença de mérito possa o juiz alterá-la.

Heinrich Brünner, München, Leipzig: Duncker, Humblot, 1914.

. Zivilprozessrecht. 2. ed. Berlin, 1932.

GUERRA, Marcelo Lima. Execução Indireta. São Paulo: Revista dos Tribunais, 1998.

KOLLMANN, Andreas. Begriffs- und Problemgeschichte des Verhältnisses von formellem und materiellem Recht. Berlin, Duncker, Humblot, 1996.

LIEBMAN, Enrico Tullio. Processo de Execução. 3. ed. São Paulo, Saraiva.

PISANI, Andrea Proto. Appunti sulla Giustizia Civile. Bari: Cacucci, 1982.

PONTES DE MIRANDA. Comentários ao Código de Processo Civil. Rio de Janeiro, Forense, 1974. v. 1. 
- Tratado das Ações. São Paulo: Revista dos Tribunais, 1970. v. 1. ROSENBERG; SCHWAB. Zivilprozessrecht. 12. ed. München:Beck, 1977.

SAVIGNY. System des heutigen römischen Rechts. Berlin, 1841.

SILVA, Ovídio A. Baptista da. Curso de Processo Civil. 4. ed. São Paulo: Revista dos Tribunais, 2000.v. 1, v. 2. . Jurisdição e Execução na tradição romano-canônica. São Paulo: Revista dos Tribunais, 1996.
TALAMINI, Eduardo. Tutela Relativa aos Deveres de Fazer e de Não Fazer. São Paulo: Revista dos Tribunais, 2001.

THEODORO JÚNIOR, Humberto. Curso de Direito Processual Civil. 39. ed. Rio de Janeiro: Forense, 2003. v. 1.

YARSHELL, Flávio Luiz. Tutela Jurisdicional Especifica nas obrigações de Declaração de Vontade! São Paulo: Malheiros, 1993. 